\title{
Synergism of antibiotic combinations against treponemes
}

\author{
I. J. ABRAMSON AND R. M. SMIBERT
}

Anaerobe Laboratory, Virginia Polytechnic Institute and State University, Blacksburg, Virginia 24061, U.S.A.

The use of combinations of drugs in the treatment of syphilis was reviewed by Willcox (1954). He appraised trends in the use of pencillin alone and in combination with arsenic, bismuth, and mercury compounds. Of the participating clinics in the study, 65.3 per cent. used penicillin alone and 28.9 per cent. used penicillin in combination with other drugs, while the remaining 5.8 per cent. used arsenic and bismuth compounds alone. All clinics in North America relied solely upon penicillin.

Most investigations of the effect of combinations of antimicrobial agents have concerned bacteria other than treponemes. Purcell, Wright, and Finland (1953) concluded from their studies in vitro with seven strains of Staphylococcus aureus that the development of resistance to penicillin, streptomycin, and erythromycin may have been delayed by use of combinations of erythromycin with either penicillin or streptomycin. Bulger and Nielson (1968) reported that evaluations in vitro of antibiotic combinations should be correlated with effectiveness in vivo. They tested strains of Staphylococcus aureus, Escherichia coli, Proteus mirabilis, Aerobacter spp., and Klebsiella spp. against seven antibiotic combinations. Synergism was observed with ampicillin-kanamycin against Streptococcus faecalis and Proteus mirabilis 17121, with cephalothin-kanamycin against Staphylococcus aureus 970, and with dicloxacillin-hetacillin against Aerobacter spp. 6160 A. Stottmeier, Woodley, and Kubica (1969) reported that $5 \mu \mathrm{g}$. $/ \mathrm{ml}$. erythromycin in combination with oxacillin-methenamine, and with isoniazid, was bacteriostatic to strains of Mycobacterium intracellulare when the antimicrobial agents were kept in contact with bacteria for $12 \mathrm{hrs}$ in concentrations attainable in man. Eickhoff, Bennett, Hayes, and Feeley (1970) examined the effects of antibiotic combinations against Pseudomonas pseudomallei. Synergism was observed with dicloxacillin and ampicillin and evidence of synergism with sulphadiazine-kanamycin, novobiocin-kanamycin, and

Received for publication June 14, 1971.

Request for reprints: Prof. R. M. Smibert, Ph.D., VPI and SU Anaerobe Laboratory, P.O. Box 49, Blacksburg, Virginia 24060 U.S.A. ampicillin-kanamycin was also reported. Williams (1971) reported that a combination of neomycinoxytetracycline was synergistic in preventing growth of Escherichia coli, Paracolo-bacterium arizona, Salmonella typhimurium, $S$. choleraesuis, and $S$. gallinarum.

The purpose of this investigation was to study the effect of various pairs of selected antibiotics on treponemes for possible synergistic activity.

\section{Material and Methods}

TREPONEME STRAIN

The Reiter strain of Treponema phagedenis was used as the test organism. Cultures were maintained as described in a previous communication (Abramson and Smibert, 1971a).

\section{PRE-REDUCED MEDIUM}

Peptone-yeast extract-glucose-serum (PYGS) medium: Peptone $M \star 2$ g. ; yeast extract 1 g.; dextrose 1 g. ; agar $0 \cdot 2$ g.; ammonium sulphate $0.05 \mathrm{~g}$.; soluble starch $\dagger 0.05 \mathrm{~g}$.; L-cysteine $\mathrm{HCl}$ hydrate $0.16 \mathrm{~g}$.; sodium bicarbonate $0.5 \mathrm{~g}$.; resa zurin solution $(25 \mathrm{mg} . / 100 \mathrm{ml}$.) distilled water) $0.4 \mathrm{ml}$.; salt solution $\left(\mathrm{MgSO}_{4} \quad 0.02\right.$ g.; $\mathrm{CaCl}_{2} .2 \mathrm{H}_{2} \mathrm{O} \quad 0.02$ g.; $\mathrm{K}_{2} \mathrm{HPO}_{4} 0.1$ g.; $\mathrm{KH}_{2} \mathrm{PO}_{4} 0.1$ g.; $\mathrm{NaCl} 0.2$ g. $/ 100 \mathrm{ml}$.) $50 \mathrm{ml}$; and distilled water $50 \mathrm{ml}$. The $\mathrm{pH}$ of the medium was adjusted to 6.5 before autoclaving and was $6 \cdot 8$ to $7 \cdot 4$ after sterilization.

\section{RABBIT SERUM}

Serum was filtered through a $0.45 \mu \mathrm{m}$. pore diame:er membrane filter, aseptically dispensed into sterile glass bottles, heat-inactivated at $58^{\circ}$ to $60^{\circ} \mathrm{C}$. for $4 \mathrm{hrs}$ and stored at $-20^{\circ} \mathrm{C}$. Sterile rabbit serum was added to tubes of pre-reduced anaerobically sterilized medium at a final concentration of 12 per cent.

Preparation of pre-reduced medium was as described in 'The Outline of Clinical Methods in Anaerobic Bacteriology' (Anaerobe Laboratory, 1970), and inoculation of cultures under oxygen-free conditions was accomplished using the V.P.I. Anaerobe Culture Systemf.

^Pfizer Diagnostics Division, New York, New York 10036, U.S.A. †Difco Laboratories, Detroit, Michigan 48201, U.S.A.

$\ddagger$ Bellco Glass, Inc., P.O. Box B, Vineland, New Jersey 08360, U.S.A. 


\section{ANTIBIOTIC COMBINATIONS}

A modification of the method described by Eickhoff and others (1970) was used in this investigation. Pairs of antibiotics with bacteriostatic combinations of 0.1 to 10 units or $\mu \mathrm{g} . / \mathrm{ml}$. of medium for the Reiter strain of Treponema phagedenis were selected for study. They were penicillin, cephalothin, bacitracin, erythromycin, vancomycin, and tetracycline. The first antibiotic was diluted and pipetted into five series of five tubes each of PYGS medium so that final concentrations were $0.001,0.01,0.1$, 1 , and 10 units or $\mu \mathrm{g} . / \mathrm{ml}$. of medium. A second antibiotic at a final concentration of 0.001 units or $\mu \mathrm{g} . / \mathrm{ml}$. of medium was pipetted into each tube of a series of five tubes containing the first antibiotic. This procedure was repeated until each one of the dilutions of the second antibiotic, $0.001,0.01,0.1,1$, and 10 units or $\mu \mathrm{g} . / \mathrm{ml}$., was pipetted into a series of five tubes of medium containing the first antibiotic. All tubes were inoculated with $0.3 \mathrm{ml}$. of a $24 \mathrm{hrs}$ culture $\left(1 \times 10^{6}\right.$ to $1 \times 10^{7}$ treponemes $/ \mathrm{ml}$.) and incubated for 3 days at $37^{\circ} \mathrm{C}$. On the third day each culture was transferred to antibiotic-free medium and incubated for an additional 3 days. After incubation each of these cultures was again subcultured into normal medium. All cultures were observed for growth daily for 14 days. Darkfield examinations were made when macroscopic observations of growth were questionable. Each antibiotic was examined for its minimal growth inhibitory and minimal bactericidal level for the Reiter strain of $T$. phagedenis using concentrations of $0.001,0.01,0.1,1,10,100,500$, and 1000 units or $\mu \mathrm{g} . / \mathrm{ml}$. of culture medium.

The definitions that we used for antibiotic synergism, additive effect and antagonism are as follows:

(1) Synergism-The inhibitory or bactericidal concentrations of both antibiotics in combination are less than that of either one of the individual antibiotics;

(2) Additive effect-The inhibitory or bactericidal concentrations of a combination of antibiotics do not differ from those of either one of the individual antibiotics;

(3) Antagonism-The inhibitory or bactericidal concentrations of a combination of antibiotics are greater than that of either one of the individual antibiotics.

\section{Results}

Neither synergism nor antagonism was found with the Reiter strain of $T$. phagedenis at growth inhibitory concentrations of bacitracin-erythromycin, bacitracincephalothin, bacitracin-penicillin, bacitracin-tetracycline, bacitracin-vancomycin, erythromycin-cephalothin, erythromycin-penicillin, erythromycin-tetracycline, erythromycin-vancomycin, cephalothin-tetracycline, cephalothin-penicillin, cephalothin-vancomycin, penicillin-tetracycline, penicillin-vancomycin, and tetracycline-vancomycin. All combinations were additive at growth inhibitory concentrations.

Synergism was observed with ten antibiotic combinations at bactericidal concentrations (Table). There was a considerable reduction in the amount of
TA B LE Synergism of various combinations of antibiotics against the Reiter strain of $\mathrm{T}$. phagedenis

\begin{tabular}{|c|c|c|c|c|}
\hline Antibiotic combinations & \multicolumn{2}{|c|}{$\begin{array}{l}\text { Concentration of } \\
\text { single antibiotic } \\
\text { at which no } \\
\text { growth appeared } \\
\text { in } 14 \text { days ( } \mu \text { g. or } \\
\text { units/ml.) }\end{array}$} & \multicolumn{2}{|c|}{$\begin{array}{l}\text { Synergistic con- } \\
\text { centrations of } \\
\text { combinations at } \\
\text { which no growth } \\
\text { appeared in } 14 \\
\text { days ( } \mu g . \text { or } \\
\text { units } / \text { ml.) }\end{array}$} \\
\hline $\boldsymbol{X}+\boldsymbol{Y}$ & $\begin{array}{l}\text { Control } \\
X\end{array}$ & $Y$ & $x+$ & $Y$ \\
\hline ErythromycinK Penicillin G & 100 & 500 & 10 & 0.001 \\
\hline Erythromycin Tetracycline & 500 & 10 & $0 \cdot 1$ & \\
\hline Erythromycin & 100 & 10 & 1 & 1 \\
\hline Cephalothin & 100 & 10 & 0.001 & \\
\hline Erythromycin & 10 & 100 & 1 & 0.001 \\
\hline Cephalothin & 10 & 100 & 1 & $0 \cdot 1$ \\
\hline Bacitracin K & 10 & 500 & 1 & 0.001 \\
\hline Tetracycline & 10 & 10 & $i$ & 1 \\
\hline Bacitracin Vancomycin & 10 & 10 & 1 & \\
\hline Erythromycin Cephalothin & 500 & 100 & 1 & 0.001 \\
\hline
\end{tabular}

antibiotic necessary to kill all the organisms in a culture when compared with the bactericidal levels of the individual antibiotics. Antagonism was not oberved with any antibiotic combination at bactericidal concentrations. An additive effect was found at bactericidal levels with combinations of cephalothin-penicillin, cephalothin-vancomycin, penicillintetracycline, penicillin-vancomycin, and tetracyclinevancomycin.

\section{Discussion}

We have studied the effect of fifteen selected combinations of antibiotics against the Reiter strain of $T$. phagedenis. Ten combinations were synergistic at bactericidal concentrations. There was no synergism at antibiotic concentrations that only inhibited growth. A much higher concentration of antibiotics, especially penicillins, is required to be bactericidal to treponemes than is required to inhibit growth (Abramson and Smibert, 1971a, b). Bactericidal concentrations of most antibiotics for cultured treponemes are high and probably cannot be attained in blood, body tissues, and fluids. Growth inhibitory levels of the penicillins, erythromycin, cephalothin, and the tetracyclines can probably be attained in blood serum against the serum requiring treponemes, but can probably not be attained in spinal fluids or aqueous humour. The high doses of penicillin required for adequate treatment of the treponematoses can probably be accounted for by the high concentrations of penicillin needed to be bactericidal. At best, blood levels attained in man are probably only growth-inhibiting for a few hours. Perhaps combinations of those antibiotics suitable for systemic use that were found to be synergistic for cultivable treponemes in vitro should be investigated 
for possible use in the treatment of the treponematoses.

\section{Summary}

Combinations of antibiotics that were synergistic at bactericidal concentrations to the Reiter strain of $T$. phagedenis were bacitracin-erythromycin, bacitracin-cephalothin, bacitracin-penicillin, bacitracintetracycline, bacitracin-vancomycin, erythromycincephalothin, erythromycin-penicillin, erythromycintetracycline, erythromycin-vancomycin, and cephalothin-tetracycline. No antagonism was found at bactericidal concentrations for any pairs of antibiotics. There was no synergism or antagonism of any pairs of antibiotics tested at growth inhibitory levels.

This investigation was supported in part, by the National Institutes of Health, Division of General Medical Sciences, Grant GM-14604.

\section{References}

Abramson, I. J., and Smibert, R. M. (1971a) Brit. F. vener. Dis., 47, 407 (1971b) Ibid., 47, 413

Anaerobe Laboratory (1970) 'Outline of Clinical Methods in Anaerobic Bacteriology', 2nd ed. Virginia Polytechnic Institute and State University, Blacksburg, Virginia 24060, U.S.A.
Bulger, R. J., and Nielson, K. (1968) Appl. Microbiol., 16, 890

Eickhoff, T. C., Bennett, J. V., Hayes, P. S., and FeELEY, J. (1970) f. infect. Dis., 121, 95

Purcell, E. M., Wright, S. S., and Finland, M. (1953) Proc. Soc. exp. Biol. (N.Y.), 82, 124

Stottmeier, K. D., Woodley, C. L., and Kubica, G. P. (1969) Appl. Microbiol., 18, 399

Willcox, R. R. (1954) Bull. Wld Hlth Org., 10, 579

Williams, B. J. (1971) Appl. Microbiol., 21, 668

Action synergique d'associations d'antibiotiques vis-à-vis des tréponèmes

SOMMAIRE

Les associations d'antibiotiques qui ont une action synergique à concentration bactéricide sur la souche Reiter de $T$. phagedenis furent: bacitracine-érythromycine, bacitracine-céphalothine, bacitracine-pénicilline, bacitracine-tétracycline, bacitracine-vancomycine, érythromycine-céphalothine, érythromycine-pénicilline, érythromycine-tétracycline, érythromycine-vancomycine et céphalothine-tétracycline. Aux concentrations bactéricides, on ne constata aucun antagonisme pour aucune paire d'antibiotiques. Au taux bactériostatiques, il n'y eut ni synergie ni antagonisme pour aucune des paires d'antibiotiques examinées. 